DEPÓSITO LEGAL ZU2020000153

Esta publicación científica en formato digital

es continuidad de la revista impresa

ISSN 0041-8811

E-ISSN 2665-0428

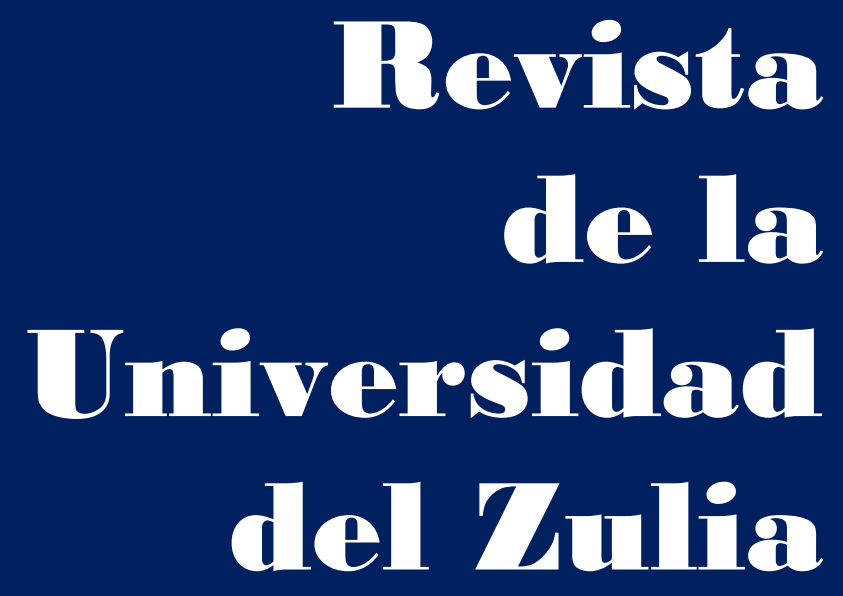

Fundada en 1947

por el Dr. Jesús Emrique Lossada

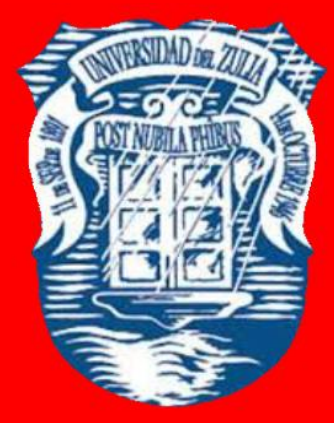

Ciencias

Sociales

y Arte

Año $12 \quad N^{\circ} 34$

Septiembre - Diciembre 2021

Tercera Época

Maracaibo-Veneruela 


\title{
Implications of the legal regulations of marketing communications in the Russian Federation
}

\author{
Maksim G. Chardymskiy * \\ Mikhail V. Gundarin ** \\ Irina Y. Ilina *** \\ Evgeniya E. Jukova **** \\ Dmitrii A. Lomonosov *****
}

ABSTRACT

The aim of implemented research is to form an understanding of the basics of legal regulation of marketing communications in the Russian Federation both among legal theorists and business practitioners interested in carrying out commercial activities in a large, dynamically developing Russian market. This article presents the study results of the legal framework in the field of marketing communications that has developed in the Russian Federation with the country's transition to the market economy. In the course of study, the authors identified the regulatory legal acts of the Russian Federation that directly or indirectly regulate marketing communications, considered the main legal norms in this area, and identified general patterns of functioning of the Russian legal framework in the field of marketing communications.

KEY WORDS: legal regulation of marketing communications; advertising; personal sales; sales promotion methods; public relations; integrated marketing communications.

${ }^{*}$ Candidate of economic sciences, associate professor of the Communicative Management Faculty, Russian State Social University, Moscow, Russia. ORCID: https://orcid.org/0000-0003-0398-7894. E-mail: mgchard@mail.ru

** Candidate of philosophical sciences, associate professor of the Communicative Management Faculty, Russian State Social University, Moscow, Russia. ORCID: https://orcid.org/0000-00027662-2880. E-mail: 7storon@list.ru

***Doctor of economic sciences, Professor of the Department of Organizational Development, Russian State University of the Humanities, Moscow, Russia. ORCID: https://orcid.org/0000-00033697-7457. E-mail: plesheeva6@yandex.ru

${ }^{* * * *}$ Candidate of economic sciences, associate professor, head of the Marketing Department, University «Synergy», Moscow, Russia. ORCID: https://orcid.org/0000-0001-7556-2241. E-mail: njinae@yandex.ru

*****Candidate of technical sciences, associate professor of the Department of Engineering Equipment of Agro-Industrial Enterprices, Primorskaya State Academy of Agriculture, Ussuriysk, Russia. ORCID: https://orcid.org/0000-0001-9818-6250. E-mail: lomonosov_dim@mail.ru 


\section{Implicaciones de las regulaciones legales de las comunicaciones de marketing en la Federación de Rusia}

RESUMEN

El objetivo de la investigación implementada es formar una comprensión de los conceptos básicos de la regulación legal de las comunicaciones de marketing en la Federación de Rusia, tanto entre los teóricos del derecho como entre los profesionales de negocios interesados en llevar a cabo actividades comerciales en un gran mercado ruso en desarrollo dinámico. Este artículo presenta los resultados del estudio del marco legal en el campo de las comunicaciones de marketing que se ha desarrollado en la Federación de Rusia con la transición del país a la economía de mercado. En el curso del estudio, los autores identificaron los actos legales regulatorios de la Federación de Rusia que regulan directa o indirectamente las comunicaciones de marketing, consideraron las principales normas legales en esta área e identificaron patrones generales de funcionamiento del marco legal ruso en el campo de las comunicaciones de marketing.

PALABRAS CLAVES: regulación legal de las comunicaciones de marketing; publicidad; ventas personales; métodos de promoción de ventas; relaciones públicas; comunicaciones integradas de marketing.

\section{Introduction}

The legal framework in the field of marketing communications in the Russian Federation (RF) began to take shape with the coming of sovereignty following the collapse of the USSR in the early 1990s. Back then, Russia was in the process of making a transition from a planned to a market economy, which required the development of a legal system corresponding to the new economic environment.

Given the fact that the legal framework for marketing communications in the Russian Federation began to evolve much later than in the advanced economies, the lawmaking practices and the mechanism for monitoring the implementation of the relevant laws and regulations in Russia are not yet firmly established. Frequent revisions of legislative and other regulatory legal instruments in the Russian Federation, including the regulation of marketing communications, which requires continuous monitoring and particular efforts from the market participants to ensure adaptability to changing legal norms, serve as one of the manifestations of such volatility. 
REVISTA DE LA UNIVERSIDAD DEL ZULIA. 3época. Año $12 \mathrm{~N}^{\circ}$ 34, 2021 Maksim G. Chardymskiy et al.// Implications of the legal regulations of marketing communications ...45-59 DOI: http://dx.doi.org/10.46925//rdluz.34.04

In the context of an emerging market, Russia engages in close international cooperation and becomes involved in the processes of globalization. The foreign trade turnover of the Russian Federation with many countries worldwide amounts to billions of dollars. The large Russian market has been an attractive venue for foreign exporters that carry a wide range of food and non-food items inwards, thus exploiting the market for services step by step. And, a booming business is known to require the building of demand and the marketing of the products provided with the use of marketing communications.

Recent sanctions by the United States, Canada, the EU, Japan, Australia and some other countries against Russia as a result of political differences and retaliatory sanctions have led to a reduction in Russian trade with some countries of the world. However, the ongoing negative processes are not able to freeze foreign economic relations with one of the largest world powers.

While entering a foreign state's market, one needs to be aware of the specifics of legislation in the area of entrepreneurship, in general, and marketing communications, in particular. The difference in the legal regulation between the Russian legislation and that of the other countries may be manifested in the restrictions on advertising and other marketing communications with regard to certain types of goods (services), methods for distributing marketing communications, the time and place of the movement of goods, the mechanism for interaction with the public authorities, etc. The following article is thus of both academic and empirical interest for researchers in international law, companies involved in business activities on the territory of the Russian Federation and implementing different types of marketing communications to promote the marketed goods and services.

\section{Methodological Foundation}

The legal aspects of marketing receive relatively little attention in the Russian scientific literature (Chardymskiy, 2014). The authors of the following publication implemented the research of the legislation serving as the backbone of the legal regulation of marketing communications in the Russian Federation.

Russian scholars generally divide marketing communications into four main types. The present approach, with minor modifications, mirrors the one suggested by some internationally recognized marketing researchers, primarily, P. Kotler (Kotler, Keller, 2011), 
whose publications are particularly popular in Russia. The major types of marketing communications are as follows (Golubkova, 2020; Marketing Communications, 2016):

1. Advertising - paying for space to promote a product or a service in mass media.

2. Personal sales - face-to-face selling in which the salesman tries to convince the customer in buying a product.

3. Sales promotion methods - the step by step proposition developed by a sales person or a company to make the process of selling more effective within a limited timeframe.

4. Public relations - a strategic communication process that builds mutually beneficial relationships between organizations and their publics, generating positive public image of the company and its products.

Alongside the four main types of marketing communications, integrated marketing communications are singled out, combining the elements of several types of marketing communications (Muzykant, 2020). Integrated marketing communications include: corporate identity, branding, promo offerings, exhibition activities, etc.

In carrying out research, the searching method, the method of classification, content analysis, induction were employed. To begin with, the authors of the article undertook a search for legal codes, laws, Presidential Edicts, the Enactments of the Government of the Russian Federation and other laws and regulations of the Russian Federation that cont ain any references to the above-mentioned types of marketing communications. Moreover, scientific literature on the subject of research was selected. Further on, by resorting to the methods of classification and content analysis, the provisions set out in the laws and regulations connected with the legal regulation of communications activities of market participants were subdivided according to the types of marketing communications and revised to be presented to a wide audience in a clearer way.

In addition to that, the scientific papers on the legal regulation of marketing communications published earlier, including the article by one of the co-authors of M. Chardymskiy, devoted to the legal aspects of Internet marketing in Russia were covered and summarized (Chardymskiy, 2014). The method of induction made it possible to draw some general conclusions about the state and peculiarities of the legal regulation of marketing communications in Russia on the basis of some particular norms. 
REVISTA DE LA UNIVERSIDAD DEL ZULIA. 3época. Año $12 \mathrm{~N}^{\circ}$ 34, 2021 Maksim G. Chardymskiy et al.// Implications of the legal regulations of marketing communications ...45-59 DOI: http://dx.doi.org/10.46925//rdluz.34.04

The following publication contains the characteristics of the legal framework and outlines the main provisions of the essential laws and regulations forming the legal norms for monitoring marketing communications in Russia; with the general conclusions being drawn.

2. The Legal Framework for Marketing Communications in the Russian Federation

The fundamental legal principles to govern marketing communications are rooted in the Constitution of the Russian Federation and in the Civil Code of the Russian Federation.

The country's constitution guarantees a single economic space throughout the Russian Federation and freedom of economic activity. Citizens are given the right to seek, receive, transmit, produce and disseminate information by any legal means (Constitution of the Russian Federation, 1993).

Part one of the Civil Code of the Russian Federation contains provisions governing certain aspects of public relations (Civil Code of the Russian Federation. Part I, 1994). Part two of the Civil Code of the Russian Federation defines the procedure for concluding and executing business contracts, which, among other things, include contracts for the provision of advertising and other services in the field of marketing communications (Civil Code of the Russian Federation. Part II, 1996). In the fourth part of the Civil Code of the Russian Federation, the use of individual tools of integrated marketing communications is regulated (Civil Code of the Russian Federation. Part IV, № 230-FZ, 2006).

Russia has implemented a number of special laws and regulations governing the use of marketing communications, advertising, in particular.

Compliance with the legislation on marketing communications is monitored by the state anti-monopoly authority. The Federal Antimonopoly Service of the Russian Federation currently performs these functions.

The Federal Antimonopoly Service of the Russian Federation is authorized to sue to prohibit the distribution of advertisements carried out in violation of federal law, to publicly refute inaccurate advertisements, to apply administrative measures, to issue orders to terminate contracts for the provision of advertising services that do not meet the requirements of the law (Civil Code of the Russian Federation. Part II, 1996). 
In practice, the perpetrators of this offence in Russia are frequently credited with distributing advertisements that infringe the legislation over a long period of time. The Federal Antimonopoly Service is not always able to quickly identify violations in the area of advertising; it takes a long time to review cases for violations of the law or to comply with the orders of the antimonopoly body with regard to suspending the distribution of improper advertising.

The regional and local laws and regulations applicable to marketing communications that comply with the federal legislation have effect in the constituent entities of the Russian Federation and municipalities. Organizing trade fairs, exhibitions, placing the outward advertising are most commonly regulated in Russia at the regional and local levels. Such legal acts occasionally govern the holding of a particular marketing event. The monitoring of the implementation of the regional and local legislation is performed by the executive authorities of appropriate levels.

A series of laws and regulations in force in the Russian Federation implicitly affects the application of marketing communications. They include:

- Law of the Russian Federation «On Protection of Consumer Rights» (Law ot the Russian Federation, № 2300-1, 1992);

- Law of the Russian Federation «On Mass Media» (Law ot the Russian Federation, № 2124-1, 1991);

- Federal Law «On Communications» (Federal Law, № 126-FZ, 2003);

- Federal Law «On the Basic Principles of State Regulation of Trading Activities in the Russian Federation» (Federal Law, № 381-FZ, 2009);

- Federal Law «On the State Language of the Russian Federation» (Federal Law, № 53FZ, 2005);

- Federal Law «On Personal Data» (Federal Law, № 152-FZ, 2006);

- Federal Law «On the Protection of Children from Information Harmful to their Health and Development» (Federal Law, № 436-FZ, 2010);

- Federal Law «On Charitable Activities and Charitable Organizations» (Federal Law, № 135-FZ, 1995); 
REVISTA DE LA UNIVERSIDAD DEL ZULIA. 3época. Año $12 \mathrm{~N}^{\circ}$ 34, 2021 Maksim G. Chardymskiy et al.// Implications of the legal regulations of marketing communications ...45-59 DOI: http://dx.doi.org/10.46925//rdluz.34.04

- Resolution of the Government of the Russian Federation «On Approval of Rules to Ensure the Availability of Information in Russian on the Imported Food Items into the Territory of the Russian Federation» (Resolution of the Government of the Russian Federation, № 1575, 1996);

- Resolution of the Government of the Russian Federation «On Measures to Ensure the Availability of Information in Russian on the Imported Non-food Items into the Territory of the Russian Federation» (Resolution of the Government of the Russian Federation, № 1037, 1997).

It's also worth noting that Russia acknowledges international and national codes of ethics in the area of marketing communications, which are of recommendatory nature. First and foremost, they are followed by members of public associations in the field of marketing, for example, the Russian Marketing Association, the Russian Association of Communication Agencies, and large companies.

Among world wide legal instruments of this type, special mention should go to the two present codes of the International Chamber of Commerce, best-known in Russia: the Consolidated ICC Code of Advertising and Marketing Communication Practice (The Consolidated ICC Code, 2006) and ICC International Code of Direct Sales (ICC International Code, 2007).

Among similar internal instruments in the Russian Federation, designed to reinforce socially responsible marketing, noteworthy are: the Code of Standards for Advertising (Code of Russian Association of Advertising Agencies, 1992), the Customary Laws and Rules of Business Advertising Practices on the territory of the Russian Federation (Laws and Rules of The Public Advertising Council, 1999), the Russian Code of Professional and Ethical Principles in the Field of Public Relations (Code of the Russian Public Relations Association, 2001).

Further on, the overview of the legal regulation of the main types of marketing communications in Russia is provided.

\section{The Legal Regulation of Advertising Activities}

Advertising activities in Russia, as well as in other countries, are subjected to the most detailed and strict legislative regulation. 
The following laws and regulations monitor advertising on the territory of the Russian Federation:

- Federal Law «On Advertising» (Federal Law, № 38-FZ, 2006);

- Decree of the President of the Russian Federation «On Guarantees of the Right of Citizens to Health Protection when Advertising is Distributed» (Decree of the President of the Russian Federation, № 161, 1995);

- Decree «On Approval of Regulation on State Supervision of Advertising of the Government of the Russian Federation» (Decree of the Government of the Russian Federation, № 1838, 2020);

- Order of the Government of the Russian Federation «About Approval of Rules of Consideration by Antimonopoly Authority of the Proceedings Initiated on Signs of Violation of the Law of the Russian Federation about Advertising» (Order of the Government of the Russian Federation, № 1922, 2020).

The main legislative instrument regulating advertising activities in the Russian Federation is the Federal Law «On Advertising» (hereinafter the Law). It ought to be remarked that the following law contains some legal norms that indirectly determine the use of other types of marketing communications, alongside advertising.

This law applies to relations in the field of advertising distributed in the Russian Federation. The law does not apply to political advertisements, announcements, nonadvertising signs, information posted on a product or its packaging.

According to the Law, advertising shall be fair and truthful. Unfair and untruthful advertisements are prohibited.

Unfair advertising is considered to be one that contains incorrect comparisons of the advertised product with other products, is created under the guise of advertising another product, defames honor, dignity or business reputation, violates the antitrust laws of Russia.

An advertisement shall be deemed untruthful if it contains untrue information on the advantages of the advertised goods, their characteristics, the value or price, the procedure for making payment for them, the terms for servicing, the manufacturer or seller of the goods, the official or public recognition, the rules of, and terms for, conducting a 
competition, game or another similar event, in particular, the deadline for acceptance of applications for participation in it, etc.

According to the Law, advertising should not induce illegal actions, call for violence and cruelty, threaten the safety of traffic, form a negative attitude towards people who do not use the advertised goods, contain pornographic information. It's forbidden to use obscene language in advertising, abusive images, comparisons and expressions regarding gender, race, nationality, profession, social category, age, language, state and religious symbols, objects of cultural heritage. In addition, advertising in which there is no part of the essential information about the advertised product, the conditions for its purchase and consumption, is prohibited.

In Russia, it's not allowed to create and distribute hidden advertising that has an unknowable effect on consumers through the use of special video inserts, dual sound recordings and other means.

The law does not allow the advertising of narcotic drugs, psychotropic substances, explosive materials, with the exception of pyrotechnics, human organs and tissues, tobacco products and smoking accessories, medical services for artificial termination of pregnancy, services for the implementation of qualification and other educational works, non-certified and unlicensed goods.

Persons whose rights and interests are violated as a result of inappropriate advertising are entitled to apply to the judicial authorities. Individuals must apply to the court; legal entities must apply to the arbitration court. Victims can file lawsuits for damages, including lost profits, for damages caused to health and property, compensation for non-pecuniary damage, public refutation of inappropriate advertising.

Other laws and regulations in the area of advertising listed above are of a private nature and address only some particular issues with regard to implementation and monitoring of advertising activities.

\section{Legal Regulation of Other Types of Marketing Communications}

Personal sales, sales promotion methods, public relations and integrated marketing communications are governed by Russian legislation generally, fragmentarily or indirectly. 
REVISTA DE LA UNIVERSIDAD DEL ZULIA. 3época. Año $12 \mathrm{~N}^{\circ}$ 34, 2021 Maksim G. Chardymskiy et al.// Implications of the legal regulations of marketing communications ...45-59 DOI: http://dx.doi.org/10.46925//rdluz.34.04

There are no separate regulatory legal acts to establish requirements for their content, presentation and distribution in the Russian Federation.

Personal sales in Russia has so far been the least affected by legal regulation among all types of marketing communications. This stems from the nature of the given type of marketing communications due to the fact that spoken messages of sellers and shop assistants are the most difficult to monitor and subject to restrictions of any kind. Generalized personal sales is regulated by the Law of the Russian Federation «On Protection of Consumer Rights» (Law of the Russian Federation, № 2300-1, 1992). This law establishes that the consumer has the right to demand the provision of the necessary and reliable information about the manufacturer, contractor or seller, his mode of operation and the goods (works, services) sold by him in a clear and accessible form in Russian. Additionally, information may be provided in other languages at the discretion of the manufacturer, contractor or seller. Thus, the law does not exclude the provision of information to consumers orally, if they consider this form available.

With regard to sales promotion methods in Russia, the terms and conditions for conducting competitions, games and other enabling activities for consumers are regulated by law. Furthermore, the organization of enabling activities is indirectly regulated by law, mainly in connection with the advertising of such events.

The Federal Law "On Advertising" establishes that the advertisement informing of a competition, game or other similar event, for participation in which it is necessary to purchase a certain product, must indicate the dates of such an event, the organizer of the event, the rules for its holding, the number of prizes, conditions for their preparation (Federal Law, № 38-FZ, 2006). Advertising of games and bets by law should not appeal to minors, to minimize the degree of risk, to condemn the non-participation of citizens in riskbased games or bets, etc.

Protection of business reputation of legal entities in Russia as a tool of public relations also belongs to legal regulation. In accordance with the part one of the Civil Code of the Russian Federation, a legal entity is entitled to demand the refutation of information discrediting its business reputation, if the person disseminating such information does not prove that it is true (Civil Code of the Russian Federation. Part I, № 5l-FZ, 1994). In this case, a refutation must be made in the same way that the information was disseminated, or 
in another similar way. In some cases, the procedure for refuting information that discredits the business reputation of a legal entity is established by the court. If this information is disseminated in the media, then the organization, along with a refutation from the defendant, has the right to demand the publication of its response in the same media. An organization whose business reputation has suffered as a result of the publication of defamatory information is also entitled to claim compensation for losses caused by the dissemination of such information. If it is impossible to establish a person who disseminated information that defames the business reputation of a legal entity, then this organization has the right to apply to the court with a statement recognizing the disseminated information as untrue.

As noted above, the use of certain integrated marketing communications tools is regulated by part four of the Civil Code. In particular, it enshrines legal protection, the procedure for state registration and the conditions for the use of company names and trademarks.

Exhibition and trade fair activities serve as another instrument of integrated marketing communications. Exhibition and trade fair activities are regulated by Resolution of the Government of the Russian Federation «On Approval of the Provision for Holding International Exhibitions of Samples of Defense Products in the Territory of the Russian Federation and Participation of Russian Organizations in Such Exhibitions at Territories of Foreign States» (Resolution of the Government of the Russian Federation, № 339, 2007). Obviously, this resolution has a very limited scope of application.

Such tools of integrated marketing communications, as merchandising, promotions, product placement, are completely outside the field of legal regulation in the Russian Federation.

\section{Conclusions}

The historical background of the legal framework for marketing communications in the Russian Federation began to take shape with the country's transition from a planned to a market economy with Russia's coming of sovereignty as an independent state following the collapse of the USSR. Over the past decades, Russia has adopted a number of specific 
REVISTA DE LA UNIVERSIDAD DEL ZULIA. 3época. Año $12 \mathrm{~N}^{\circ}$ 34, 2021 Maksim G. Chardymskiy et al.// Implications of the legal regulations of marketing communications ...45-59 DOI: http://dx.doi.org/10.46925//rdluz.34.04

laws and regulations in the given area. The application of marketing communications is indirectly determined by other laws and regulations.

The legal regulation of marketing communications in Russia is implemented at all levels of public and municipal administration: federal, regional, and local. Primarily, advertising is subject to the legal regulation. The main legislative instrument regulating its application is the Federal Law «On Advertising». The Law provides both general requirements for advertising and legal norms for some particular ways of distributing advertising, advertising of certain types of goods, self-regulatory governance of advertising, state control and accountability for violation of the Law of the Russian Federation «On Advertising». Other types of marketing communications, such as personal sales, sales promotion methods, public relations, as well as integrated marketing communications, are not provided for by any specific legal instruments. Their application is, to a certain extent, governed by the Federal Law «On Advertising», the Civil Code of the Russian Federation and some other laws and regulations.

The legal framework for marketing communications in the Russian Federation has been frequently changed. One example is the Law «On Advertising» that is amended, on average, two to three times per year. Such amendments are generally non-essential and individual in their nature; nevertheless, entrepreneurs and managers are to provide continuous monitoring of the Russian legislation and track any changes in it.

The state supervision of the application of marketing communications in the country is carried out by the Federal Antimonopoly Service of the Russian Federation, including its regional departments. On the other hand, the supervision is scarcely ever conducted expeditiously.

The main results of the study were discussed at the International Social Congress at the Russian State Social University in 2019. The participants of the discussion expressed their opinion about the indirect and fragmentary regulation of marketing communications in the legislation of the Russian Federation, with the exception of advertising, which is due both to the nature of these types of marketing communications and insufficient elaboration of these issues by the legislative authorities. Most of the speakers agreed on the need for a more comprehensive and detailed legal regulation of public relations, sales promotion methods, personal sales, as well as event marketing and product placement. 
REVISTA DE LA UNIVERSIDAD DEL ZULIA. 3época. Año $12 \mathrm{~N}^{\circ}$ 34, 2021 Maksim G. Chardymskiy et al.// Implications of the legal regulations of marketing communications ...45-59 DOI: http://dx.doi.org/10.46925//rdluz.34.04

The legal framework in the field of marketing communications has been functioning in the Russian Federation for 30 years. It has passed the stage of formation and is gradually being improved, approaching the standards of international law.

Despite the formation of a fairly comprehensive legal framework for marketing communications, there are gaps in Russian legislation that allow the free use of many marketing communication tools. These gaps need to be eliminated by specifying the legal regulation of all types of marketing communications, without infringing on the freedom of entrepreneurship.

\section{References}

Chardymskiy, M. (2014). Legal aspects of Internet marketing in Russia // Practical marketing. 2014. №. 4. P. 10-13.

Golubkova, E.N. (2020). Integrated marketing communications. 3rd ed., rev. and exp. M.: Yurayt, 2020. 363 p. URL: https://urait.ru/bcode/450157.

Kotler, P., Keller, K.L. (2011). Marketing Management. 14th edition. Upper Saddle River (NJ). Prentice Hall. 2011. 812 p.

Marketing Communications / Under the general ed. of O.N. Romanenkova. M.: Urait, 2016. $456 \mathrm{p}$.

Muzykant, V.L. (2020). The Essentials of Integrated Communications: Theory and Modern Practics: in 2 Parts. Part l: Strategies, Effective Branding. M.: Urait, 2020. 352 p. URL: https://urait.ru/bcode/451340.

Civil Code of the Russian Federation. (Part I) № 5l-FZ of November 30, 1994 (as amended by Civil Code of the Russian Federation. (Part I) № 21l-FZ of June 11, 2021).

Civil Code of the Russian Federation. (Part II) № 14-FZ of January 26, 1996 (as amended by Civil Code of the Russian Federation. (Part II) № 33-FZ of March 9, 2021).

Civil Code of the Russian Federation. (Part IV) № 230-FZ of December 18, 2006 (as amended by Civil Code of the Russian Federation. (Part IV) № 213-FZ of June 11, 2021).

Constitution of the Russian Federation of December 12, 1993 (as amended by Federal Constitutional Law № 1-FKZ of March 14, 2020).

Decree № 1838 of November 16, 2020 «On Approval of Regulation on State Supervision of Advertising of the Government of the Russian Federation».

Decree of the President of the Russian Federation № 161 of February 17, 1995 «On Guarantees of the Right of Citizens to Health Protection when Advertising is Distributed» 
REVISTA DE LA UNIVERSIDAD DEL ZULIA. 3época. Año $12 \mathrm{~N}^{\circ}$ 34, 2021

Maksim G. Chardymskiy et al.// Implications of the legal regulations of marketing communications ...45-59

DOI: http://dx.doi.org/10.46925//rdluz.34.04

(as amended by Decree of the President of the Russian Federation № 533 of April 23, 2007 «On Guarantees of the Right of Citizens to Health Protection when Advertising is Distributed»).

Federal Law № 38-FZ of March 13, 2006 «On Advertising» (as amended by Federal Law № 150-FZ of May 26, 2021 «On Advertising»).

Federal Law № 53-FZ of June 1, 2005 «On the State Language of the Russian Federation» (as amended by Federal Law № 101-FZ of May 1, 2014 « On the State Language of the Russian Federation »).

Federal Law № 126-FZ of July 7, 2003 «On Communications» (as amended by Federal Law № 535-FZ of December 30, 2020 «On Communications»).

Federal Law № 135-FZ of August 11, 1995 «On Charitable Activities and Volunteerism» (as amended by Federal Law № 113-FZ of April 7, 2020 «On Charitable Activities and Volunteerism»).

Federal Law № 152-FZ of July 27, 2006 «On Personal Data» (as amended by Federal Law № 205-FZ of July 23, 2013 «On Personal Data»).

Federal Law № 381-FZ of December 28, 2009 «On the Basic Principles of State Regulation of Trading Activities in the Russian Federation» (as amended by Federal Law № 488-FZ of December 25, 2018 «On the Basic Principles of State Regulation of Trading Activities in the Russian Federation»).

Federal Law № 436-FZ of December 29, 2010 «On the Protection of Children from Information Harmful to their Health and Development» (as amended by Federal Law № 264-FZ of July l, 2021 «On the Protection of Children from Information Harmful to their Health and Development»).

ICC International Code of Direct Sales (2007 Edition).

Law of the Russian Federation № 2124-1 of December 27, 1991 «On Mass Media» (as amended by Law of the Russian Federation № 290-FZ of July 1, 2021 «On Mass Media»).

Law of the Russian Federation № 2300-1 of February 7, 1992 «On Protection of Consumer Rights» (as amended by Law of the Russian Federation № 160-FZ of December 22, 2020 «On Protection of Consumer Rights»).

Order of the Government of the Russian Federation № 1922 of November 24, 2020 «About Approval of Rules of Consideration by Antimonopoly Authority of the Proceedings Initiated on Signs of Violation of the Law of the Russian Federation about Advertising».

Resolution of the Government of the Russian Federation № 339 of June 2, 2007 «On Approval of the Provision for Holding International Exhibitions of Samples of Defense Products in the Territory of the Russian Federation and Participation of Russian Organizations in Such Exhibitions at Territories of Foreign States» (as amended by 
Resolution of the Government of the Russian Federation № 1150 of December 12, 2013 «On Approval of the Provision for Holding International Exhibitions of Samples of Defense Products in the Territory of the Russian Federation and Participation of Russian Organizations in Such Exhibitions at Territories of Foreign States»).

Resolution of the Government of the Russian Federation № 1575 of December 27, 1996 «On Approval of Rules to Ensure the Availability of Information in Russian on the Imported Food Items into the Territory of the Russian Federation» (as amended by Resolution of the Government of the Russian Federation № 295 of April 16, 2001 «On Approval of Rules to Ensure the Availability of Information in Russian on the Imported Food Items into the Territory of the Russian Federation»).

Resolution of the Government of the Russian Federation № 1037 of August 15, 1997 «On Measures to Ensure the Availability of Information in Russian on the Imported Non-food Items into the Territory of the Russian Federation».

The Code of Standards for Advertising adopted by the Russian Association of Advertising Agencies of January 21, 1992.

The Consolidated ICC Code of Advertising and Marketing Communication Practice (2006 Edition).

The Customary Laws and Rules of Business Advertising Practices in the Territory of the Russian Federation adopted by the Public Advertising Council of September 27, 1996 (as amended by the Customary Laws and Rules of Business Advertising Practices in the territory of the Russian Federation adopted by the Public Advertising Council of June 17, 1999).

The Russian Code of Professional and Ethical Principles in the Field of Public Relations Adopted by the Russian Public Relations Association of September 26, 2001. 